\title{
HOPE-BASED INTERVENTION UNTUK MENURUNKAN STRES SERTA MENINGKATKAN HARAPAN DAN SUBJECTIVE WELL-BEING PADA PENDERITA DIABETES MELLITUS TIPE 2
}

\author{
Tiara D. Sosialita \\ Hamidah \\ Program Magister Profesi Psikologi \\ Universitas Airlangga Surabaya
}

\begin{abstract}
Abstrak Penelitian ini bertujuan untuk menguji efektivitas hope-based intervention untuk menurunkan stres serta meningkatkan harapan dan subjective well-being pada penderita diabetes mellitus tipe 2 menggunakan desain eksperimen pretest posttest control group design pada 20 orang penderita Diabetes Mellitus tipe 2 berusia 20-40 tahun. Alat ukur yang digunakan berupa skala stres adaptasi Perceived Stress Scale dari Cohen (1988), skala harapan adaptasi Hope Scale dari Snyder (2003) serta skala subjective well-being yang merupakan kombinasi dan adaptasi dari Satisfaction with Life Scale oleh Diener (1985) dan The Affect Balance Scale oleh Bradburn (1969). Hasil analisa data menunjukkan bahwa terdapat perbedaan yang signifikan antara skor stres pada kelompok eksperimen dengan skor stres pada kelompok kontrol setelah adanya pemberian intervensi $(p=0,038)$, serta ada perbedaan yang signifikan antara skor harapan $(p=0,011)$ dan skor subjective well-being $(p=0,000)$ pada kelompok eksperimen dengan kelompok kontrol. Adapun nilai efektivitas dari hope-based intervention tergolong sedang untuk variabel stres $(E S=0,45)$ serta tergolong besar untuk variabel harapan $(E S=1,83)$ dan subjective well-being ( $E S=3,87$ ). Hal ini menunjukkan bahwa hope-based intervention efektif untuk menurunkan stres serta meningkatkan harapan dan subjective well-being pada penderita Diabetes Mellitus tipe 2.
\end{abstract}

Kata kunci : Hope-based intervention, Stres, Harapan, Subjective well-being, Diabetes mellitus

PSIKOISLAMIKA. Jurnal Psikologi Islam (JPI) copyright @ 2015 Pusat Penelitan dan Layanan Psikologi. Volume 12 Nomor 1 Tahun 2015

\section{PENDAHULUAN}

Keberadaan penyakit kronis semakin meningkat secara global tiap tahunnya dan telah ditetapkan sebagai salah satu epidemi kesehatan di masyarakat. WHO menjabarkan bahwa penyakit kronis merupakan penyakit jangka panjang dan secara umum memiliki kemajuan yang lama, misalnya penyakit jantung, stroke, kanker, penyakit pernapasan kronis, depresi dan diabetes (WHO, 2015). Diabetes Mellitus merupakan penyakit kronis yang sering muncul di seluruh dunia (Sarafino, 2002). Berdasarkan data dari WHO (World Health Organization) dan IDF (International Diabetes Federation), jumlah penderita Diabetes Mellitus mencapai 285 juta pada tahun 2010 dan diperkirakan terus meningkat hingga mencapai 438 juta pada tahun 2030 (Duggleby, dkk., 2010).

Prevalensi Diabetes Mellitus di Indonesia sendiri dilaporkan terus mengalami peningkatan sebanyak tiga kali lipat dalam 10 tahun terakhir (Depkes, 2014). Penderita Diabetes Mellitus di Indonesia pada tahun 2012 sebanyak 21,3 juta orang dan menempati 
urutan ke-4 penderita Diabetes Mellitus terbanyak di dunia setelah Amerika Serikat, China dan India (Cox \& Gonder-Frederick, 2012). Survei nasional yang dilakukan pada tahun 2011/2012 di ibukota seluruh propinsi Indonesia menunjukkan bahwa prevalensi penderita Diabetes Mellitus mencapai $14,7 \%$ di daerah perkotaan dan $7,2 \%$ di daerah pedesaan dari seluruh penduduk Indonesia (Depkes, 2014). Menurut data Survei Sosial Ekonomi Nasional (SUSENAS) tahun 2013-2014, 8,1\% penduduk lakilaki dewasa (> 18 tahun) menderita sakit kronis dan $10,5 \%$ penduduk wanita dewasa menderita sakit kronis (Depkes, 2014).

Fenomena meningkatnya prevalensi penyakit Diabetes Mellitus membuat dampak yang ditimbulkan pada penderita pun perlu menjadi perhatian. Diabetes Mellitus diasosiasikan dengan penurunan sementara atau permanen dalam hal fisik, vokasional dan aktivitas sosial (Delamater, 2009). Stres juga ditemukan muncul pada kebanyakan penderita Diabetes Mellitus, terutama berkaitan dengan perubahan gaya hidup yang meliputi tuntutantuntutan yang harus dipenuhi, seperti pantangan untuk mengonsumsi jenis makanan tertentu, menjaga aktivitas olahraga serta cek gula darah teratur (Diabetes Control \& Complications Trial Research Group, 2011). Perubahan-perubahan yang terjadi tidak hanya meliputi penderita Diabetes Mellitus, namun juga berdampak pada lingkungan misalnya pendapatan yang menurun, terbatasnya interaksi dengan keluarga, serta stres secara fisiologis maupun psikologis. Perubahan yang dialami oleh penderita Diabetes Mellitus dapat berasal dari lingkungan sosial, misalnya keterpisahan dari keluarga, teman dan pihak lain yang merupakan sumber kepuasan bagi dirinya (Delamater, 2009). Penderita Diabetes Mellitus juga kehilangan peran penting yang selama ini disandangnya, berkurangnya autonomi serta kontrol terhadap diri sendiri karena penyakit yang diderita (Cox \& Gonder-Frederick, 2012). Perubahanperubahan yang terjadi pada penderita tersebut menyebabkan memburuknya persepsi terhadap diri sendiri, munculnya emosi-emosi distress seperti kecemasan, depresi, ketidakberdayaan dan kemarahan (Delamater, 2009).

Berdasarkan teori stres dari Cohen (1988), diketahui bahwa stres timbul sebagai akibat dari adanya kejadian tidak terduga, tidak dapat dikontrol atau dikendalika, serta kelebihan beban dalam hidup. Penderita Diabetes Mellitus yang didiagnosa menderita penyakit ini sebelumnya tidak menyangka bahwa ia akan menderita penyakit yang menuntut perubahan dalam segala aspek hidupnya. Hal tersebut dianggap sebagai datangnya kejadian tidak terduga dan yang tidak dapat dikontrol atau dikendalikan. Tuntutan dan keharusan untuk mengubah gaya hidup sehari-hari sebagai bagian dari penanganan penyakit Diabetes Mellitus juga menimbulkan beban bagi penderita. Situasi yang dihadapi penderita penyakit kronis rentan menimbulkan simptom-simptom stres baik secara fisiologi maupun psikologis, frustasi dan kemarahan terutama bila penyakitnya diluar perkiraan, serta kekhawatiran akan pemenuhan kebutuhan hidup di masa depan (Cohen,1983).

Penderita Diabetes Mellitus cenderung merespon keadaan di luar dirinya dengan kurang baik sehingga mengakibatkan kondisi mental maupun emosional menjadi terganggu. Cohen (1988) mengungkapkan bahwa respon yang ditunjukkan tersebut akan mempengaruhi kesehatan fisik dimana stres dimanifestasikan pada perubahan fisiologis, reaksi kognitif, reaksi emosional, dan respon perilaku. Penderita Diabetes Mellitus menjadi lebih mudah tersinggung, didominasi emosi-emosi negatif, tekanan darah meninggi, detak jantung naik, hingga otot menjadi tegang. Secara umum penderita Diabetes Mellitus mengalami stres karena mendapat informasi bahwa penyakitnya sukar disembuhkan dan diharuskan untuk mengubah gaya hidup dengan melakukan diet ketat. Penderita merasa penderitaannya akibat penyakit tersebut akan berlangsung selamanya dan terbayang masa depan yang suram.

Perubahan dalam kehidupan, pola hidup, serta tuntutan yang harus dilakukan oleh penderita Diabetes Mellitus dapat membuat penderita pesimis, dan mengembangkan emosi-emosi negatif. Hal ini didukung pula oleh penelitian dari Westburg dan Guindon (2004) bahwa penyakit kronis berdampak pada kesehatan emosi dan psikologis individu dimana penderita menjadi kurang memiliki harapan dalam menatap hidupnya. Penderita Diabetes Mellitus dilaporkan cenderung memiliki diposisi negatif yang lebih kuat daripada atribut positif, dimana hal tersebut berhubungan dengan rendahnya tingkat harapan yang dimiliki (Vieth, 2012). Kurangnya harapan yang dimiliki membuat penderita Diabetes Mellitus kurang memiliki optimisme ke depan, mengembangkan emosi-emosi negatif, serta kurang menikmati hidupnya. Adanya penurunan pada beberapa aspek kehidupan tersebut, yaitu aspek kesehatan fisik, aspek psikologis dan aspek sosial tersebut mengakibatkan kebahagian, kepuasan serta kualitas hidup penderita juga menurun ketika penderita tidak mampu menyikapi secara baik (Lyubomirsky, dkk., 
2005). Aspek kebahagiaan, kepuasan, emosi-emosi dan kualitas hidup tersebut mempengaruhi kondisi subjective well-being individu (Healey-Ogden \& Austin, 2011). Hal tersebut sesuai pula dengan penelitian Tkach dan Lyubomirsky (2006) yang menyatakan bahwa Diabetes Mellitus memberikan dampak negatif pada subjective well-being penderita dan cenderung kurang mengembangkan afek positif, dimana adanya afek positif merupakan ciri utama dari subjective well-being.

Sehubungan dengan kondisi yang dialami oleh penderita Diabetes Mellitus tipe 2 dimana banyak dari mereka merasakan penurunan dan gangguan pada berbagai domain fungsional (fisik, emosi, kognitif dan sosial) selama periode waktu (Scioli, dkk., 2013), maka sebuah intervensi tepat perlu dilakukan untuk membantu penderita mengatasi psikopatologis dan meningkatkan well-being. Intervensi yang tepat diperlukan agar individu dapat beradaptasi dengan tuntutan situasi yang penuh tekanan, sehingga mereka tidak mudah merasa stres, depresi dan cemas terhadap kejadiankejadian di sekitarnya (Snyder, 2003). Beberapa penelitian mengungkapkan bahwa adanya harapan merupakan suatu hal yang penting bagi pasien penyakit kronis dan memiliki pengaruh signifikan terhadap kesehatan fisik dan mental pasien secara keseluruhan (Ho, dkk., 2012).

Intervensi berbasis model teoritis harapan direkomendasikan sebagai salah satu cara untuk mengurangi distres psikologis, mengatasi permasalahan yang timbul berkenaan dengan penyakit atau kehilangan, maupun meningkatkan kehidupan individu ke arah yang lebih baik. Strategi-strategi memperkuat harapan tersebut dapat meningkatkan pemikiran penuh harap, serta diasosiasikan juga dengan peningkatan subjective well-being dan penurunan simptom-simptom stres (Weis \& Sperikados, 2011). Sejalan dengan hasil tersebut, sebuah penelitian dari Klausner (2008) juga mengungkapkan bahwa intervensi berbasis harapan (hope-based intervention) terbukti efektif memperkuat harapan sehingga memperkuat kepuasan hidup dan kesehatan mental penderita penyakit kronis. Berbagai penelitian dengan melakukan intervensi harapan (hope intervention) ataupun strategi-strategi meningkatkan harapan (hope enhancement strategies) menunjukkan hasil bahwa individu dengan harapan kuat lebih sering sukses menghadapi stressor dan kesuksesan yang diperoleh tersebut memberikan feedback yang berguna untuk semakin menguatkan harapan mereka (Thio \& Elliot, 2005; Parenteau, dkk., 2006; Rosenberg,
2010; Redlich, dkk., 2010; Pattison \& Lee, 2011; Koehn, dkk., 2012). Penelitian tersebut membuktikan bahwa perubahan tingkat harapan yang dimiliki individu dapat mempengaruhi konstruk psikologis lainnya, dimana peningkatan harapan diasosiasikan dengan perilaku adaptif baik secara kognitif, afektif maupun perilaku serta kepuasan hidup yang baik, dimana komponen tersebut merupakan domain dari subjective well-being, serta mampu menurunkan distres psikologis.

Melihat paparan tersebut, penulis menemukan terdapat masalah pada penderita penyakit kronis, khususnya Diabetes Mellitus tipe 2. Penderita menunjukkan simptom-simptom stres, harapan rendah, serta adanya afek negatif yang lebih dominan daripada afek positif dan persepsi akan kehidupan yang pesimis sehingga penderita cenderung merespon situasi dengan negatif dan akhirnya berdampak pada kesehatan fisik dan psikologis penderita sendiri. Penulis meneliti efektivitas pemberian intervensi berbasis harapan (hope-based intervention) sebagai salah satu strategi yang dapat memunculkan harapan pada penderita Diabetes Mellitus tipe 2 dan diharapkan dengan munculnya harapan tersebut membuat penderita Diabetes Mellitus memiliki subjective well-being yang lebih baik serta menurunkan simptom-simptom stres yang dirasakan.

\section{METODE}

Penelitian menggunakan kuasi eksperimen dengan non-randomized pretest-posttest control group design pada 20 orang partisipan yang menderita Diabetes Mellitus tipe 2 dengan GDS > 150 di wilayah kerja Puskesmas Medokan Ayu Surabaya (sebanyak $55 \%$ partisipan telah mengidap Diabetes Mellitus tipe 2 selama 3 - 5 tahun, $30 \%$ partisipan telah mengidap Diabetes Mellitus tipe 2 selama 1-2 tahun, $10 \%$ partisipan telah mengidap Diabetes Mellitus tipe 2 selama 6-10 tahun dan sebanyak $5 \%$ subjek penelitian telah mengidap Diabetes Mellitus tipe 2 selama lebih dari 10 tahun), usia 20-40 tahun (35\% partisipan berada pada rentang usia 20-30 tahun, sedangkan $65 \%$ partisipan berusia antara 31-40 tahun), pendidikan minimal SMA (60\% partisipan berpendidikan terakhir SMA dan sebanyak $40 \%$ partisipan berpendidikan SMK), memiliki skor stres kategori ringan hingga tinggi, serta memiliki skor harapan dan subjective well-being kategori sedang hingga rendah. Penetapan sampel dari populasi dilakukan dengan melakukan pemasangan pada masing-masing kelompok eksperimen dan kelompok 
kontrol sesuai dengan karakteristik yang telah ditetapkan. Pembentukan kelompok eksperimen dan kelompok kontrol kemudian dilakukan berdasarkan matching variabel harapan dengan tingkat sedang hingga rendah.

\section{Pengumpulan Data}

Skala Stres

Penulis menggunakan Perceived Stress Scale dari Cohen (1988) sebagai instrumen untuk mengukur persepsi stres. Item-item didesain untuk mengetahui bagaimana respon stres individu ketika dihadapkan pada situasi yang tidak terprediksi, tidak dapat dikontrol maupun kejadian stressful. Pertanyaan dalam PSS seputar perasaan dan pikiran yang dirasakan selama sebulan terakhir. Item-item dalam PSS juga berkorelasi dengan status kesehatan sehingga sesuai dengan penelitian yang akan dilakukan oleh penulis. PSS menunjukkan korelasi dengan: Stress Measures, Self-Reported Health and Health Services Measures, Health Behavior Measures, Smoking Status, Help Seeking Behavior. Selain itu, PSS juga menunjukkan korelasi dengan stres yang ditimbulkan oleh kejadian sehari-hari, kejadian luar biasa dalam hidup, dan perubahan dalam strategi coping.

\section{Skala Harapan}

Penulis menggunakan Hope Scale (Snyder, 1991) yang ditujukan untuk mengukur tingkat harapan yang dimiliki individu. Hope Scale mengukur dua dimensi dari harapan yang saling berinteraksi. Skala harapan tersebut berisi 12 pernyataan: 4 pernyataan mengukur agency (misal, "Saya mencapai tujuan yang telah Saya tetapkan sendiri"), 4 pernyataan mengukur pathways (misalnya, "Ada banyak cara yang bisa dilakukan untuk menyelesaikan masalah apapun"), dan 4 pernyataan lainnya merupakan distraktor. Penilaian skala didasarkan pada total skor pada subskala agency dan pathways untuk menentukan keseluruhan skor harapan (Snyder, 2003).

\section{Skala Subjective Well-Being}

Skala subjective well-being pada penelitian ini menggunakan kombinasi dan adaptasi dari Satisfaction with Life Scale (SWLS) yang dikembangkan oleh
Diener dkk (1984) untuk mengukur evaluasi kognitif yaitu nilai kepuasan hidup individu secara global dan the affect balance scale oleh Bradburn (1969) untuk mengukur evaluasi afeksi individu. Skala subjective well being terdiri dari 2 indikator yaitu indikator kognitif dan afeksi yang meliputi aspek satisfaction, positive affect dan negative affect.

\section{Hasil dan Pembahasan}

Hasil Uji Beda Antara Kelompok Eksperimen dan Kelompok Kontrol

\begin{tabular}{lll}
\hline \multicolumn{3}{c}{ Independent sample t-test } \\
\hline $\begin{array}{l}\text { Gain score } \\
\text { stres }\end{array}$ & $\begin{array}{l}\text { Kelompok } \\
\text { Kelompok eksperimen }\end{array}$ & Sig.2 tailed \\
\hline $\begin{array}{l}\text { Gain score } \\
\text { harapan }\end{array}$ & $\begin{array}{l}\text { Kelompok eksperimen } \\
\text { Kelompok kontrol }\end{array}$ & 0,011 \\
\hline $\begin{array}{l}\text { Gain score } \\
\text { SWB }\end{array}$ & $\begin{array}{l}\text { Kelompok eksperimen } \\
\text { Kelompok kontrol }\end{array}$ & 0,000 \\
\hline Gain score SWB & $\begin{array}{l}\text { Kelompok eksperimen } \\
\text { Kelompok kontrol }\end{array}$ & 0,000 \\
\hline
\end{tabular}

Berdasarkan tabel hasil uji beda, diketahui bahwa nilai signifikansi pada gain score stres sebesar 0,038 $<0,05$ sehingga dapat disimpulkan bahwa terdapat perbedaan yang signifikan antara gain score stres pada kelompok eksperimen dan kelompok kontrol setelah adanya pemberian perlakuan berupa hopebased intervention. Nilai signifikansi pada gain score harapan sebesar $0,011<0,05$, sehingga terlihat bahwa terdapat perbedaan yang signifikan antara gain score harapan pada kelompok eksperimen dan kelompok kontrol setelah adanya pemberian perlakuan berupa hope-based intervention. Nilai signifikansi gain score subjective well-being sebesar $0,000<0,05$ sehingga dapat disimpulkan bahwa terdapat perbedaan yang signifikan antara gain score subjective well-being pada kelompok eksperimen dan kelompok kontrol setelah adanya pemberian perlakuan berupa hope-based intervention. Kesimpulannya adalah terdapat perbedaan antara kelompok eksperimen dan kelompok kontrol pada masing-masing gain score stres, gain score harapan dan gain score subjective well-being dimana pada kelompok eksperimen diberikan perlakuan berupa hope-based intervention sedangkan kelompok kontrol tidak diberikan hope-based intervention. 
Efektivitas Hope-Based Intervention

\begin{tabular}{llllllll}
\hline & Kelompok & Mean Pretest & SD Pretest & Mean Posttest & SD Posttest & Nilai ES & Kategori \\
\hline Stres & Eksperimen & 20,7 & 2,847 & 17,2 & 2,994 & 0,45 & $\begin{array}{l}\text { Efektivitas } \\
\text { Sedang }\end{array}$ \\
\hline Harapan & Eksperimen & 20,5 & 3,281 & 25,1 & 3,742 & 1,83 & $\begin{array}{l}\text { Efektivitas } \\
\text { Besar }\end{array}$ \\
\hline SWB & Eksperimen & 17 & 3,406 & 22,7 & 4,000 & 3,87 & $\begin{array}{l}\text { Efektivitas } \\
\text { Besar }\end{array}$ \\
\hline
\end{tabular}

Berdasarkan tabel uji efektivitas, diketahui bahwa nilai efektivitas hope-based intervention untuk stres adalah 0,45 berada di rentang $0,5 \geq$ $x \leq 0,7$, sehingga dapat dikatakan hope-based intervention memiliki efektivitas yang sedang untuk menurunkan stres pada kelompok eksperimen. Nilai efektivitas hope-based intervention untuk harapan adalah $1,83 \geq 0,8$ sehingga dapat dikatakan bahwa hope-based intervention memiliki efektivitas yang besar untuk meningkatkan harapan pada kelompok eksperimen. Nilai efektivitas hope-based intervention untuk subjective well-being adalah $3,87 \geq 0,8$ sehingga dapat dikatakan bahwa hopebased intervention memiliki efektivitas yang besar untuk meningkatkan subjective well-being pada kelompok eksperimen.

\section{Efektivitas Hope-Based Intervention}

Hasil penelitian menunjukkan bahwa hopebased intervention efektif menurunkan stres serta meningkatkan harapan dan subjective well-being penderita Diabetes Mellitus tipe 2. Hal ini berarti hope-based intervention berpengaruh secara signifikan terhadap penurunan stres serta peningkatan harapan dan subjective well-being pada penderita Diabetes Mellitus tipe 2. Hal ini serupa dengan hasil penelitian sebelumnya yang dilakukan oleh Weis \& Sperikados (2011) dimana penelitian tersebut menghasilkan kesimpulan bahwa hope-based intervention efektif untuk meningkatkan harapan dan subjective well-being pada penderita penyakit kronis yang mengalami stres. Berdasarkan uraian tersebut, dapat disimpulkan bahwa hope-based intervention memiliki efek yang signifikan pada hampir seluruh anggota kelompok eksperimen.

\section{Penurunan Stres}

Hasil dari penelitian ini yang menunjukkan bahwa penurunan stres partisipan memiliki effect size yang tergolong sedang, namun efektivitas peningkatan harapan dan subjective well-being yang tergolong besar juga sejalan dengan penelitian terdahulu. Penelitian yang telah dilakukan oleh Duggleby, dkk. (2010) menyebutkan bahwa strategi-strategi intervensi yang berbasis peningkatan harapan, efektif dalam meningkatkan harapan dan wellbeing partisipan namun memiliki hubungan yang kurang kuat dengan penurunan stres partisipan. Hal ini terjadi karena dalam proses pelaksanaan hope-based intervention, strategi-strategi dan aktivitas berfokus pada peningkatan harapan dan improvisasi individu ke arah yang lebih positif. Hal tersebut juga terjadi dalam pelaksanaan hopebased intervention dalam penelitian ini, dimana proses pemberian intervensi kepada partisipan memang lebih banyak aktivitas dan tugas yang berhubungan dengan harapan sebagai penderita Diabetes Mellitus tipe 2.

\section{Peningkatan Harapan dan Subjective Well- Being}

Peningkatan subjective well-being ini dapat terjadi karena dalam pelaksanaan hope-based intervention terdapat aktivitas-aktivitas dan strategi-strategi untuk meningkatkan harapan bagi penderita (Weis \& Sperikados, 2011). Aktivitas dan strategi peningkatan harapan tersebut berguna dalam menggali tujuan-tujuan terkait kesehatan penderita dan menumbuhkan motivasi untuk mencapainya dengan usaha internal maupun eksternal.

Sejalan dengan temuan tersebut, penelitian yang dilakukan oleh Scioli (2013) menunjukkan hasil bahwa hope-based intervention yang menggunakan strategi-strategi memperkuat harapan, secara signifikan mampu meningkatkan harapan dan kepuasan hidup serta menurunkan distres psikologis. Strategistrategi tersebut didasarkan pada teori harapan yang kemudian direkomendasikan sebagai salah satu cara mengurangi distres psikologis, mengatasi permasalahan yang timbul akibat penyakit, serta meningkatkan well-being. Pemberian hope-based intervention kepada partisipan penelitian ini pun berpedoman pada teori harapan yang disesuaikan dengan kondisi penderita Diabetes Mellitus tipe 2. 
Faktor yang Mempengaruhi Stres, Harapan dan Subjective Well-Being Penderita

Temuan lain adalah telah diketahui bahwa lama mengidap Diabetes Mellitus dan frekuensi kontrol kesehatan berpengaruh terhadap ketegorisasi stres penderita, dimana kemudian hal tersebut juga berpengaruh terhadap harapan dan subjective wellbeing. Penderita yang mengalami stres ringan adalah penderita yang mengidap Diabetes Mellitus antara 1-2 tahun dan masih tergolong rutin melakukan kontrol kesehatan di Puskesmas. Penderita yang telah mengidap Diabetes Mellitus selama 3 tahun atau lebih dan tergolong tidak rutin melakukan kontrol kesehatan, lebih banyak masuk dalam kategori stres sedang-tinggi. Hal ini dapat disebabkan karena adanya keoptimisan dan harapan pada penderita yang baru 1-2 tahun mengidap Diabetes Mellitus, meskipun mereka juga harus mengalami perubahan gaya hidup dan aktivitas sehari-hari. Banyak dari partisipan, yang telah mengidap Diabetes Mellitus selama 3-5 tahun atau lebih merasa telah pasrah dengan keadaannya sehingga enggan mengembangkan harapan dan putus asa.

Hal tersebut juga sesuai dengan hasil penelitian dari Stanton, dkk. (2002) yang mendukung temuan bahwa harapan merupakan salah satu bentuk mekanisme coping yang positif pada penderita penyakit kronis yang mengalami stres terkait dengan perjalanan penyakitnya maupun dengan terapi yang dijalani. Adanya harapan membuat penderita penyakit kronis lebih kuat dalam menghadapi stressor yang dialami sehari-hari, selain itu membuat penderita memiliki motivasi untuk mencapai kondisi yang lebih sehat. Hal tersebut juga berpengaruh terhadap perilaku menjaga kesehatan, aktivitas terapi, serta kesediaan menjalankan berbagai saran dari dokter.

Sebuah penelitian yang dilakukan oleh Vieth, dkk. (2012) mengungkapkan bahwa peningkatan harapan yang dihasilkan dari pelaksanaan hope-based intervention juga efektif meningkatkan disposisi afek positif dan mengurangi afek negatif. Hal tersebut membuat partisipan dapat berfungsi secara optimal dalam menghadapi kondisi sakit Diabetes Mellitus tipe 2 yang dialami. Adanya pemberian intervensi berbasis harapan terbukti efektif untuk menurunkan afek negatif dan meningkatkan harapan yang dikaitkan juga dengan peningkatan well-being pada penderita Diabetes Mellitus.

\section{DISKUSI}

Banyak penelitian yang penulis temukan mengungkapkan pentingnya intervensi berbasis harapan (hope-based intervention) bagi penderita penyakit kronis ataupun pasien paliatif, akan tetapi penelitian-penelitian yang melakukan intervensi berbasis harapan pada penderita Diabetes Mellitus tipe 2 sangat sulit penulis jumpai sejauh ini. Intervensi bagi penderita Diabetes Mellitus kebanyakan terkait kesehatan fisik penderita, padahal banyak jurnal penelitian yang mengungkapkan bahwa aspek psikologis khususnya harapan merupakan komponen vital dalam menentukan kesembuhan. Pembahasan mengenai intervensi berbasis harapan pada penderita penyakit kronis, termasuk Diabetes Mellitus juga lebih sering ditemukan melalui jurnaljurnal penelitian, buku, atau abstraksi dari luar negeri khususnya wilayah negara barat, meskipun banyak dari intervensi tersebut ditujukan pada pasien paliatif. Penelitian ini bertujuan untuk melihat efektivitas hope-based intervention dalam menurunkan stres serta meningkatkan harapan dan subjective well-being pada penderita Diabetes Mellitus tipe 2.

Pelaksanaan hope-based intervention yang dilakukan secara kelompok dapat membuat masingmasing partisipan dalam kelompok bercerita dan berbagi pengalaman mengenai kondisi sakit yang dialami. Kegiatan kelompok untuk berbagi cerita atau pengalaman dan diskusi di setiap sesinya mampu membuat para partisipan terbuka dan menyadari kondisi yang saling dialami. Intervensi dilakukan dalam setting kelompok karena secara teori, hopeful thinking merefleksikan sebuah proses transaksional (Snyder, 2003). Hal tersebut membuat masing-masing partisipan dapat bertukar pengalaman dan saling memberikan masukan dalam menghadapi permasalahan yang dihadapi. Partisipan menjadi memiliki dukungan sekaligus cara berpikir baru untuk menyelesaikan masalah sehari-hari terkait dengan Diabetes Mellitus yang dialami.

Adanya proses diskusi yang dilakukan pada setiap sesinya membuat para partisipan menemukan harapan baru untuk dapat menjaga dan mempertahankan kondisi optimal bagi penderita Diabetes Mellitus tipe 2. Adamya dukungan kelompok juga terlihat di setiap sesinya. Partisipan yang aktif mampu memberikan pengaruh yang positif bagi anggota yang lain. Adanya dukungan ini dapat meningkatkan kesadaran diri dan permasalahannya sehingga anggota kelompok mendapatkan insight untuk menyiapkan diri menghadapi setiap permasalahan yanga ada (Lyubomirsky, dkk., 2005). Hal tersebut juga sesuai dengan pelaksanaan hope-based intervention yang 
dilakukan dalam setting kelompok dengan pertimbangan bahwa proses terapeutik akan lebih berjalan optimal dengan adanya suatu kondisi interaksional dalam satu kelompok (Snyder, 2003).

Proses terapeutik kelompok dalam hope-based intervention menjalin terbentuknya rasa persamaan kondisi dan kebersamaan diantara masing-masing anggota kelompok. Partisipan mampu belajar memandang atau menelaah suatu permasalahan dari berbagai sudut pandang yang berbeda. Adanya persamaan kondisi sakit Diabetes Mellitus yang dialami mampu memotivasi masing-masing partisipan untuk mencapai tujuan dan impian yang dimiliki, bertahan dengan kondisi dan permasalahan sakit yang dialami, meningkatkan kepuasan terhadap diri dan keadaan, serta mendorong partisipan untuk befokus pada potensi tanpa berkutat dalam afeksi negatif. Hal ini serupa dengan pendapat Snyder (2003) bahwa hope-based intervention dapat memberikan kesempatan untuk dapat meningkatkan harapan, membangun kekuatan dan pengalaman hidup yang lebih baik.

Bagi peneliti selanjutnya yang tertarik dengan pemberian hope-based intervention diharapkan

\section{DAFTAR PUSTAKA}

Argyle, M. (1999). Causes and correlates of happiness. Well-being: The foundations of hedonic psychology. New York: Russell Sage Foundation.

Azwar, S. (2007). Penyusunan skala psikologi. Yogyakarta: Pustaka Pelajar.

Barnum, D.D., Snyder, C.R., Rapoff, M.A., Mani, M.M., \& Thompson, R. (1998). Hope and social support in psychological adjusmment of children who have survived burn injuries and their matched controls. Child Health Care, 27, 15-30.

Benzein, E., Norberg, A., \& Britt-Inger, S. (2010). The meaning of the lived experience of hope in patients with cancer in palliative home care. Palliative Medicine, 15, 117-126.

Bernheim, J.L., Theuns, P., Mazaheri, M., Hofmans, J., Fliege, H., \& Rose, M. (2006). The potential of anamnestic comparative self-assessment (ACSA) to reduce bias in the measurement of subjective well-being. Journal of Happiness Studies, 7, 227-250.

Carr, A. (2004). Positive psychology. New York: Brunner-Routledge. dapat melakukan pengembangan dari penelitian ini dengan menggunakan intervensi yang sama namun pada sampel yang berbeda. Hal ini diharapkan mampu memberikan bukti bagi efektivitas hopebased intervention untuk menurunkan stres serta meningkatkan harapan dan subjective wellbeing.

Selain itu, simpulan dari penelitian ini menunjukkan bahwa hope-based intervention efektif untuk menurunkan stres serta meningkatkan harapan dan subjective well-being pada penderita Diabetes Mellitus tipe 2, meskipun efektivitasnya tergolong sedang pada penurunan stres partisipan. Hal ini menjadi masukan bagi penelitian selanjutnya yang juga tertarik menggunakan hope-based intervention untuk menurunkan stres serta meningkatkan harapan dan subjective well-being, untuk mempertimbangkan adanya pemberian tugas, aktivitas ataupun materi yang lebih berfokus pada stres karena modul hopebased intervention yang diadaptasi dalam penelitian ini kurang memiliki tugas, aktivitas maupun materi mengenai stres.

Coulehan, J. (2011). Deep hope: A song without words. Theory of Medical Biotechnology Journal, 32, 143-160.

Cox, D.J., \& Gonder-Frederick, L. (2012). Major developments in behavioral diabetes research. Journal of Consulting and Clinical Psychology, 60, 628-638.

Cutcliffe, J.R., \& Herth, K. (2012). The concept of hope in nursing 1: Its origins, background, and nature. British Journal of Nursing, 11, 832-840.

Delamater, A.M. (2009). Insulin-dependent diabetes mellitus. The Clinical Psychologist, 46,198205.

Diabetes Control and Complications Trial Research Group. (2011). The effect of intensive treatment of diabetes on the development and progression of long-term complications in insulin-dependent diabetes mellitus. New England Journal of Medicine, 329, 977-986.

Diabetes mellitus dapat dicegah. (2014, Juni). Depkes [on-line]. Diakses pada tanggal 11 Pebruari 2015 dari www.depkes.go.id. 
Diener, E. (2000). Subjective well-being: The science of happiness and a proposal foe a nation index. Washington, DC: American Psychological Association.

Duggleby, W., Holtslander, L., Kylma, J., Hammond, C., \& Williams, A. (2010). Metasynthesis of the hope experience of family caregivers of persons with chronic illmess. Qualitative Health Research, 20, 148-158. Nice Journal [on-line]. Diakses pada tanggal 15 Pebruari 2015 http://www.nice.org.uk/nicemedia/ pdf/MHAOPEExecutiveSummary

Eddington, N., \& Shuman, R. (2005, Agustus). Subjective Well-being (happiness). Texcpe [on-line]. Diakses pada tanggal 23 Maret 2015 dari http://www.texcpe.com/cpe/PDF/ cahappiness.pdf.

Feldman, D.B., \& Snyder, C. R. (2005). Hope and the meaningful life: Theoretical and empirical associations between goal-directed thinking and life meaning. Journal of Social and Clinical Psychology, 24, 401-421.

Healey-Odgen, M.J,. \& Austin, W.J. (2011). Uncovering the lived experience of well-being. Qualitative Health Research, 21, 85-96.

Hellman, C.M., Pittman, M.K., \& Munoz, R.T. (2013). The first twenty years of the will and the ways: An examination of score reliability distribution on Snyder's dispositional hope scale. Journal of Happiness Study, 14, 723-729.

Herth, K. (2009). Fostering hope in terminally ill people. Journal of Advanced Nursing, 15, 1250-1259.

Ho, S.M., Ho, J.W., Pau, B.K., Hui, B.P., Wong, R.S., \& Chu, A.T. (2012). Hope-based intervention for individuals susceptible to colorectal cancer: A pilot study. Familial Cancer Journal, 11, 545-551.

Hurlock, E.B. (5 $5^{\text {th }}$. ed.). (1997). Psikolgi perkembangan: Suatu pendekatan sepanjang rentang kehidupan. Jakarta: Erlangga.

Kerlinger, F.N. (2004). (eds.). Asas-Asas Penelitian Behavioral. Yogyakarta: Gadjah Mada University Press.

Koehn, C., O'neill, L., \& Sherry, J. (2012). Hopefocused intervention in substance abuse counselling. International Journal of Mental Health \& Addiction, 10, 441-452.

Klausner, E., Snyder, C. R., \& Cheavens, J. (2008). A hope-based group treatment for depressed older adult outpatients, physical illness and depression in older adults: $A$ handbook of theory, research, and practice. New York: Plenum.

Latipun. (2008). Psikologi eksperimen. Malang: UMM Press.

Lopez, S.J., Floyd, R.K., Ulven, J.C., \& Snyder, C.R. (2003). Hope therapy: Helping clients build a house of hope: Theory, measures, and applications. San Diego: Academic.

Lyubomirsky, S., King, L., \& Diener, E. (2005). The Benefits of frequent positive affect: Does happiness lead to success?. Psychological Bulletin, 6, 803-855. ACSU [on-line]. Diakses pada tanggal 26 Maret 2015 dari http: / / www. acsu.buffalo.edu./happiness.

Madan, S., \& Pakenham, K.I. (2014). The stressbuffering effects of hope on adjustment to multiple sclerosis. International Journal of Behavioral \& Medical,21, 877-890.

Mahat, G., Scoloveno, M.A., \& Whalen, C. (2002). Positive health practices of urban minority adolescents. The Journal of School Nursing, $18,163-169$.

Marques, Susana C., Lopez, Shane J., \& Pais-Ribeiro, J.L. (2009). Building hope for the future: A program to foster strengths in middle-school students. Journal of Happiness Study, 12, 139-152.

Parenteau, S.C., Gallant, S. Sarosiek, I., \& McCallum, R.W. (2006). The role of hope in the psychological adjustment of gastropareutic patients receiving the gastric pacemaker: A longitudinal study. Journal of Clinical Psychology in Medical Setting, 13, 49-56.

Pattison, N.A., \& Lee, C. (2011). Hope against hope in cancer at the end of life. Journal of Religious Health, 50, 731-742.

Priyatno, D. (2009). Lima jam belajar olah data dengan SPSS 17 for windows. Yogyakarta: Andi Offset.

Redlich, D., Hadas-Lidor, N., Weiss, P., \& Amirav, I. (2010). Mediated learning experience intervention increases hope of family members coping with a relative with severe mental illness. Community \& Mental Health Journal, 46, 409-415.

Rosenberg, L. (2010). Hope for people with mental illness and substance use disorders. Journal of Behavioral Health Service \& Research, 
$37,135-146$.

Sarwono, S.W.. (2004). Psikologi kesehatan. Jakarta: Raja Grafindo Persada.

Scioli, A., Chamberlin, C.M., Samor, C.M., LaPointe, A.B., Campbell, T., \& Macleod, A.R. (2013). A prospective study of hope, optmism, and health. Psychological Reports, 81, 723-733.

Shorey, H.S., Snyder, C.R., Yang, X., \& Lewin, M.R. (2010). The role of hope as a mediator in recollected parenting, adult attachment, and mental health. Journal of Social and Clinical Psychology, 22, 685-715.

Snyder, C.R., Sympson, S.C., Ybasco, F.C., Borders, T.F., Babyak, M.A., \& Higgins, R.L. (1996). Development and validation of the state hope scale. Journal Personality, Social, and Psychology, 70, 321-335.

Snyder, C.R., Feldman, D.B., Taylor, J.D., Schroeder, L.L., \& Adams, V. (2000). The roles of hopeful thinking in preventing problems and enhancing strengths. Applied and Preventive Psychology, 15, 262-295.

Snyder, C.R., Ilardi, S.S., Cheavens, J., Michael, S.T., Yamhure, L., \& Sympson, S. (2000). The role of hope in cognitive-behavior therapies. Cognitive Therapy \& Research Journal, 24, 747-762.

Snyder, C.R., Harris, C., Anderson, J.R., Holleran, S.A., Irving, L.M., Sigmon, S.T., dkk. (2005). The will and the ways: Development and validation of an individual-differences measure of hope. Journal of Personality and Social Psychology, 60, 570-585.

Snyder, C.R., LaPointe, A.B., Crowson, J.J., Jr., \& Early, S. (2003). Preferences of high-hope and low-hope people for self-referential input. Cognition and Emotion, 12, 807-823.

Snyder, C.R., \& Lopez, S.J. (2003). Positive psychological assessment: $A$ handbook of models and measures. Washington, DC: American Psychological Association.

Snyder, C.R., \& Lopez, S.J. (2007). Positive psychology: The scientific and practical explorations of human strengths. California: Sage Publications, Inc.

Stanton, A.L., Danoff-Burg, S., \& Huggins, M.E.
(2002). The first year after breast cancer diagnosis: Hope and coping strategies as predictors of adjustment. Psychooncology, 11, 93-102.

Sugiyono. (2001). Statistik nonparametrik untuk penelitian. Bandung: Alfabeta.

Sugiyono. (2010). Statistika untuk penelitian. Bandung: Alfabeta.

Taylor, S. (2 ${ }^{\text {nd }}$. ed.). (1991). Health psychology. USA: McGraw-Hill.

Thio, I.M., \& Elliot, T.R. (2005). Hope, social support, and postpartum depression: Disentangling the mediating effects of negative affectivity. Journal of Clinical Psychology in Medical Setting, 12, 293-299.

Tkach, C., \& Lyubomirsky, S. (2006). How do people pursue happiness?: Relating personality, happiness-increasing strategies, and wellbeing. Journal of Happiness Studies, 7, 183-225.

Vieth, A.Z., Hagglund, K.J., Clay, D.L., Frank, R.G., Thayer, J.F., Johnson, J.C., \& Goldstein, D.E. (2012). The contribution of hope and affectivity to diabetes-related disability: An exploratory study. Journal of Clinical Psychology in Medical Setting, 4, 65-77.

Weis, R., \& Speridakos, E.C. (2011). Psychology of well-being: A meta-analysis of hope enhancement strategies in clinical and community settings. Theory, Research and Practice, 5, 34-44.

Westburg, N.G., \& Guindon, M.H. (2004). Hope, attitudes, emotions, and expectations in healthcare providers of services to patients infected with HIV. AIDS \& Behavioral Journal, 8, 158-169.

WHO. (2015, Januari). Chronic ilness task force. WHO [on-line]. Diakses pada tanggal 08 Pebruari 2015 dari http://www.who.int/ mediacentre/factsheets/fs311/en/.

WHO. (2015, Januari). Diabetes mellitus. WHO [on-line]. Diakses pada tanggal 08 Februari 2015 dari http://www.who.int/topics/ diabetes/en/ 